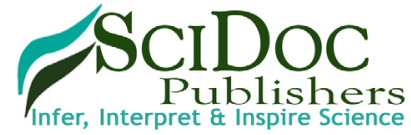

\section{Effect of Citrus Essential Oil as a Preservative on the Proximate Composition Of Stored Smoked Clupeids, E. Fimbriata And S. Maderensis}

Research Article

\author{
Oladosu-Ajayi, $\mathrm{RN}^{1}$, Dienye $\mathrm{HE}^{4}$, George $\mathrm{FOA}^{2}$, Alegbeleye $\mathrm{WO}^{2}$, Bankole $\mathrm{MO}^{3}$
}

${ }^{1}$ Department of Fisheries Technology, Federal College of Freshwater Fisheries Technology (FCFFT), New Bussa, Niger State, Nigeria.

${ }^{2}$ Department of Aquaculture and Fisheries Management, Federal University of Agriculture, Abeokuta, Ogun State, Nigeria.

${ }^{3}$ Department of Microbiology, Federal University of Agriculture, Abeokuta, Ogun State, Nigeria.

${ }^{4}$ Department of Fisheries. University of Portharcourt, Rivers State, Nigeria.

\title{
Abstract
}

This study examined the preservative potentials of lemon peel oil for smoked Clupeids, Ethmalosa fimbriata and Sardinella maderensis and its resultant effect on the nutrient content. Two hundred samples (200 nos: 100 each of both fish for proximate analysis) were divided into two and a part coated with the essential oil while the other part was not (both bonga and sardine). Triplicate samples of fish were aseptically stored in cartons and evaluated weekly for nutrient composition during a 12 -week storage period. Effect of the essential oil was significantly $(\mathrm{p}<0.05)$ pronounced on the nutrient content of samples with crude protein (CP) and fat contents of preserved samples increasing weekly (Bonga: CP 43.75-44.25\% and Fat: 8.85-9.60\%; Sardine: CP 42.75-44.55\%, Fat 8.40-9.50\%) while CP and fat decreased (Bonga: CP 38.50-13.50\% Fat: 5.85-1.85\%, Sardine: CP: $40.25-14.65 \%$, Fat: $6.35-1.45 \%$ ) in unpreserved samples. This study concluded that lemon essential oil elongated the shelf life and improved proximate composition of clupeids.

\section{Introduction}

Fish is globally the commonest source of protein for many homes. It serves as a principal source of dietary protein which is expensive in relation to other protein foods. Fish protein compares favorably with fat of milk, egg and meat in its amino acid composition [13]. The advantages of fish as food include its ease of digestion and high nutritional value. Despite being a good protein source, fish also provides other nutrients such as fat soluble vitamins and are good sources of some minerals like calcium, phosphorus and iron [8]. They also contain significant amounts of all essential amino acids, particularly lysine in which cereals are relatively poor. Fish protein can be used therefore to complement the amino acids pattern and improve the overall protein quality of mixed diet [17]. Fish preservation involves the various methods used in the prevention of fish spoilage and lengthening of life its shelf. Preservation techniques therefore work by interrupting one or more of these requirements. The central concern of fish processing is to prevent fish from deteriorating and the most obvious method for preserving the quality of fish is to keep it alive until ready for cooking and eating without which so much will be lost to post-harvest losses [16]. Smoking is desirable due to the procedural ease and consumer preferences. Also wood smoke imparts a desirable taste on fish, toughens and dehydrates fish muscle thereby providing longer shelf life, lowering $\mathrm{pH}$ and making fish less susceptible to spoilage [2, 15]. Smoke contributes greatly to fish preservation by acting as an effective antioxidant, bacteriostatic and bactericidal agent, as well as providing a protective film on the surface of the smoked fish. Clupeids are the most valuable family food fishes in the world in the order Clupeiformes. They are the group of fish with a form most like the original form of the bony fishes (Teleostei) from which all other bony fishes evolved. They are characteristically small $(<50 \mathrm{~cm})$, schooling fish with silvery bellies and sides and greenish gray backs (Dewey, 2014). E. fimbriata occurs in inshore waters, lagoons and more than $300 \mathrm{~km}$ up rivers. It is euryhaline (i.e. has ability to tolerate varying salt concentrations) and feeds by filtering phytoplankton (chiefly diatoms and breeds) throughout the year [3]. The Clupeid fishing season normally extends from October to May with a peak period of three months from January to March [14]. Sardinella maderensis

*Corresponding Author:

Oladosu-Ajayi, R.N

Department of Fisheries Technology, Federal College of Freshwater Fisheries Technology (FCFFT), New Bussa. Niger State, Nigeria.

Tel: +2348035244860

E-mail: oladosuajayi@gmail.com

Received: September 12, 2020

Accepted: September 26, 2020

Published: September 28, 2020

Citation: Oladosu-Ajayi, RN, Dienye HE, George FOA, Alegbeleye WO, Bankole MO. Effect of Citrus Essential Oil as a Preservative on the Proximate Composition Of Stored Smoked Clupeids, E. Fimbriata And S. Maderensis. Int J Food Sci Nutr Diet. 2020;9(6):477-481. doi: http://dx.doi.org/10.19070/2326-3350-2000084

Copyright: Oladosu-Ajayi, $\mathbf{R N}^{\circ}$ 2020. This is an open-access article distributed under the terms of the Creative Commons Attribution License, which permits unrestricted use, distribution and reproduction in any medium, provided the original author and source are credited. 
is an oceanodromous pelagic filter-feeding clupeid. It is usually found in "schools" at either the surface or middle of the water body [14]. It is a silvery fish that is similar to the round Sardinella (Sardinella aurita) but differs with its grey caudal fins having black tips.

\section{Materials and Method}

Freshly smoked samples (200 nos: 100 each of both fish) of both bonga (Ethmalosa fimbriata) and sardine (Sardinella maderensis) were bought from Makun-omi market, in Ijebu-ode, Ogun State. These were divided into two parts and a part coated with the essential oils while the other part was not (for both bonga and sardine). The coated samples were put in white polyethylene bags and placed in cartons and a second part packed in carton with polyethylene bags uncoated. These were then stored at ambient temperature $\left( \pm 25^{\circ} \mathrm{C}\right)$ for twelve weeks. The samples were assessed weekly for its proximate composition in a 3-month shelf life study (to see the effect of essential oil on the nutrients of the stored smoked clupeids). This was done by taking $10 \mathrm{~g}$ each in triplicates, put in sample bowls and taken for analysis according to Ayeloja (2016). The parameters determined include moisture content, crude protein content, lipid content, ash content and crude fiber content.

\section{Proximate Composition}

The proximate composition of the smoked stored clupeid samples was determined in triplicate and the parameters determined include:

Moisture content: The moisture content of each sample was estimated using the oven drying method (AOAC, 1995). Five gram of homogenous mixture was placed in weighed crucibles maintained at $1050 \mathrm{C}$ in an oven until constant weight was obtained. The samples were then transferred to a desiccator to cool at ambient temperature and weighed again. The difference in weight of samples before and after oven drying (weight loss) indicated the moisture content expressed in percentage.

Protein content: The total nitrogen (crude protein) was determined by the Kjeldahl method [5]. A known weight $(0.5 \mathrm{~g})$ of prepared fish sample was weighed on a nitrogen-free paper. The paper was wrapped round the sample and dropped at the bottom of the Kjeldahl digestion flask together with 6 glass beads and 4 spatula-full granular mixtures of $\mathrm{CuSO}_{4}$ and $\mathrm{K}_{2} \mathrm{SO}_{4}$ as catalyst. Concentrated $\mathrm{H}_{2} \mathrm{SO}_{4}(20 \mathrm{ml})$ was carefully added. The flask was gently heated on a heating mantle in an inclined position in a fume cupboard until full digestion (when the liquid changed from brown to colorless). The content of the flask was transferred to a clean $100 \mathrm{ml}$ volumetric flask and made up to volume. Twenty five aliquot was used for distillation; and total nitrogen was determined colourimetrically.

Lipid content: Lipid determination was carried out using the Soxhlet method with petroleum ether as solvent [5]. Five grams of homogenous sample mixture was put in the thimble of the Soxhlet extractor and the solvent was poured into the distillation flask. Then, the condenser was connected to the top of the extractor and distillation flask containing the solvent to its bottom. The distillation flask was then put on a heating mantle from where the heat which boiled and vapourized the solvent was produced.
The solvent penetrated into the homogenized fish flesh and resulted in the extraction of oil which was left in the flask while the vapourized solvent continued for six hours for total oil extraction to be achieved.

Ash content: Ash content of fish samples was determined by incineration in a carbolite Sheffield muffle furnace at $500^{\circ} \mathrm{C}$ [5]. The difference in weight of the fish samples before and after incineration was taken as the ash content and calculated thus:

Ash content $=($ weight of $($ burned sample + dish $)-$ weigh of dish / Weight of sample) $\times 100 \%$

Crude Fiber Content: Two grams of smoked fish was weighed into a round bottomed flask and $200 \mathrm{ml}$ of pre-heated $\mathrm{H}_{2} \mathrm{SO}_{4}$ solution was added, and the solution was gently boiled for about 30 minutes while maintaining constant volume of acid by the addition of hot water. A Buckner flask funnel fitted with Whatman filter was pre-heated by pouring hot water into the funnel. The boiled acid sample mixture was then filtered hot through the funnel under sufficient suction. The residue was washed several times with boiling water (until the residue was neutral to litmus paper) and transferred back into a beaker. Then $200 \mathrm{ml}$ of $\mathrm{NaOH}$ was heated to boiling point and kept at boiling temperature under a reflux condenser until used. Residue was washed back into flask with $200 \mathrm{ml}$ of the boiling $\mathrm{NaOH}$ solution. The flask was connected with condenser and immediately filtered through the Gooch crucible. After thorough washing with boiling water, it was washed with $15 \mathrm{ml}$ of $95 \%$ ethanol, and then the crucible was dried $110^{\circ} \mathrm{C}$ to constant weight, cooled in a desiccator and weighed. The weight loss which gives the crude fiber content [5] and was calculated as:

$\%$ Crude fiber $=((\mathrm{A}-\mathrm{B}) / \mathrm{C}) \times 100$

Where: $\mathrm{A}=$ weight of dry crucible and sample, $\mathrm{B}=$ weight of incinerated crucible and ash, $\mathrm{C}=$ sample weight.

\section{Statistical Analysis}

Data obtained at each stage of the study was statistically analyzed using Analysis of Variance (ANOVA) and the means separated using the Duncan Multiple Range Test according to Sanders (1990). The statistical package used for this was SPSS 17.

\section{Results}

The result of the proximate composition (\%) of unpreserved smoked Sardine (Sardinella maderensis) packaged in polyethylene bags during 12 weeks storage is presented in Table 1. The moisture content ranged from $2.10 \pm 0.14$ at week 12 to $7.65 \pm 0.21$ at week 1 . The moisture content decreased with increase in storage period. The crude protein, lipid, crude fibre ranged from $14.65 \pm$ 0.21 to $40.25 \pm 0.35,1.45 \pm 0.07$ to $6.35 \pm 0.12$ and $2.15 \pm 0.07$ to $5.40 \pm 0.28$ at week 12 and week 1 respectively. The ash also ranged from $2.05 \pm 0.07$ to $6.65 \pm 0.21$ while the nitrogen free extract (NFE) increased weekly ranging from $38.43 \pm 6.8$ at week 1 to $77.50 \pm 0.14$ at week 12 .

The moisture content and crude fibre of smoked Sardine (Sardinella maderensis) preserved with lemon essential oil and packaged 
in polyethylene bags during storage period ranged from $4.40 \pm$ 0.14 to $7.35 \pm 0.07$ and $6.30 \pm 0.14$ to $7.75 \pm 0.35$ at week 12 and week 1 respectively. The crude protein, lipid, ash and NFE all increased during storage period with values ranging from $42.75 \pm$ 0.35 to $44.55 \pm 0.07,8.40 \pm 0.14$ to $9.50 \pm 0.42,6.90 \pm 0.14$ to $7.10 \pm 0.14$ and $26.75 \pm 1.06$ to $28.15 \pm 0.64$ at week 1 and week 12 respectively (Table 2 ). All the increase and decrease were not significantly $(\mathrm{p}<0.05)$ different from one another except for that of moisture content.

There was no significant difference $(\mathrm{p}<0.05)$ in the increase in proximate composition (\%) of smoked Bonga, Ethmalosa fimbriata preserved with lemon essential oil and packaged in polyethylene bags as presented in Table 3. The moisture content ranged from $3.90 \pm 0.14$ at week 12 to $7.10 \pm 0.14$ at week 12 . The crude protein, lipid, crude fibre, ash and NFE also ranged from 43.75 \pm 1.06 to $44.25 \pm 0.35,8.85 \pm 0.21$ to $9.60 \pm 0.14,6.85 \pm 0.50$ to $7.10 \pm 0.42,6.75 \pm 0.35$ to $26.70 \pm 1.56$ to $27.60 \pm 1.13$ at week 1 and week 12 respectively.

The unpreserved smoked Bonga (Ethmalosa fimbriata) packaged in polyethylene bags had all its proximate components except the NFE significantly $(p<0.05)$ decreasing weekly throughout the storage period (Table 4). All its proximate components decreased as the storage period progressed from week 1 to week 12 . Moisture content $(2.40 \pm 0.14$ at week 12 to $8.10 \pm 0.14$ at week 1$)$, crude protein (13.50 \pm 0.71 at week 12 to $38.50 \pm 0.71$ at week 1$)$, lipid (1.85 \pm 0.21 at week 12 to $5.85 \pm 0.21$ at week 1$)$, crude fibre $(1.40 \pm 0.14$ at week 12 to $7.13 \pm 0.04$ at week 1$)$ and ash $(2.35 \pm$ 0.21 at week 12 to $6.35 \pm 0.21$ at week 1 ).

Table 1. Proximate Composition (\%) of unpreserved smoked Sardine (Sardinella maderensis) during storage.

\begin{tabular}{|c|c|c|c|c|c|c|}
\hline Week & Moisture & $\begin{array}{c}\text { Crude Pro- } \\
\text { tein }\end{array}$ & Lipid & $\begin{array}{c}\text { Crude } \\
\text { Fibre }\end{array}$ & Ash & NFE \\
\hline 1 & $7.65 \pm 0.21^{\mathrm{a}}$ & $40.25 \pm 0.35^{\mathrm{a}}$ & $6.35 \pm 0.12^{\mathrm{ab}}$ & $5.40 \pm 0.28^{\mathrm{a}}$ & $6.65 \pm 0.21^{\mathrm{a}}$ & $38.43 \pm 6.82^{\mathrm{fg}}$ \\
\hline 2 & $7.20 \pm 0.28^{\mathrm{a}}$ & $39.50 \pm 0.71^{\mathrm{a}}$ & $6.65 \pm 0.21^{\mathrm{a}}$ & $5.35 \pm 0.21^{\mathrm{a}}$ & $6.10 \pm 0.14^{\mathrm{b}}$ & $35.20 \pm 0.57^{\mathrm{g}}$ \\
\hline 3 & $6.25 \pm 0.35^{\mathrm{b}}$ & $35.50 \pm 0.71^{\mathrm{b}}$ & $5.85 \pm 0.21^{\mathrm{b}}$ & $4.90 \pm 0.14^{\mathrm{a}}$ & $5.20 \pm 0.28^{\mathrm{c}}$ & $42.30 \pm 0.28^{\mathrm{f}}$ \\
\hline 4 & $5.25 \pm 0.35^{\mathrm{c}}$ & $30.70 \pm 0.99^{\mathrm{c}}$ & $4.75 \pm 0.35^{\mathrm{c}}$ & $4.25 \pm 0.35^{\mathrm{b}}$ & $4.60 \pm 0.14^{\mathrm{d}}$ & $50.55 \pm 0.64^{\mathrm{e}}$ \\
\hline 5 & $5.00 \pm 0.28^{\mathrm{c}}$ & $26.00 \pm 1.41^{\mathrm{d}}$ & $4.10 \pm 0.14^{\mathrm{d}}$ & $4.10 \pm 0.14^{\mathrm{b}}$ & $4.10 \pm 0.14^{\mathrm{e}}$ & $56.70 \pm 1.56^{\mathrm{d}}$ \\
\hline 6 & $4.75 \pm 0.35^{\mathrm{c}}$ & $23.55 \pm 0.64^{\mathrm{e}}$ & $3.65 \pm 0.21^{\mathrm{d}}$ & $3.80 \pm 0.28^{\mathrm{bc}}$ & $3.60 \pm 0.28^{\mathrm{f}}$ & $56.70 \pm 1.56^{\mathrm{d}}$ \\
\hline 7 & $3.90 \pm 0.14^{\mathrm{d}}$ & $21.50 \pm 0.71^{\mathrm{f}}$ & $3.00 \pm 0.28^{\mathrm{e}}$ & $4.00 \pm 0.28^{\mathrm{b}}$ & $3.15 \pm 0.07^{\mathrm{g}}$ & $64.45 \pm 0.49^{\mathrm{c}}$ \\
\hline 8 & $3.45 \pm 0.07^{\mathrm{de}}$ & $20.50 \pm 0.71^{\mathrm{f}}$ & $2.70 \pm 0.42^{\mathrm{ef}}$ & $3.75 \pm 0.35^{\mathrm{bc}}$ & $2.75 \pm 0.35^{\mathrm{gh}}$ & $66.85 \pm 0.21^{\mathrm{bc}}$ \\
\hline 9 & $3.10 \pm 0.14^{\mathrm{ef}}$ & $18.75 \pm 0.35^{\mathrm{g}}$ & $2.45 \pm 0.35^{\mathrm{ef}}$ & $3.30 \pm 0.14^{\mathrm{cd}}$ & $2.90 \pm 0.14^{\mathrm{gh}}$ & $69.50 \pm 1.13^{\mathrm{b}}$ \\
\hline 10 & $2.75 \pm 0.07^{\mathrm{fg}}$ & $20.15 \pm 0.94^{\mathrm{fg}}$ & $2.15 \pm 0.21^{\mathrm{fg}}$ & $2.90 \pm 0.14^{\mathrm{de}}$ & $2.95 \pm 0.07^{\mathrm{gh}}$ & $69.10 \pm 0.71^{\mathrm{bc}}$ \\
\hline 11 & $2.40 \pm 0.14^{\mathrm{gh}}$ & $15.60 \pm 0.57^{\mathrm{h}}$ & $1.70 \pm 0.14^{\mathrm{gh}}$ & $2.55 \pm 0.07^{\mathrm{ef}}$ & $2.65 \pm 0.21^{\mathrm{h}}$ & $75.10 \pm 0.28^{\mathrm{a}}$ \\
\hline 12 & $2.10 \pm 0.14^{\mathrm{h}}$ & $14.65 \pm 0.21^{\mathrm{h}}$ & $1.45 \pm 0.07^{\mathrm{h}}$ & $2.15 \pm 0.07^{\mathrm{f}}$ & $2.05 \pm 0.07^{\mathrm{i}}$ & $77.50 \pm 0.14^{\mathrm{d}}$ \\
\hline
\end{tabular}

$\mathrm{NFE}=$ Nitrogen free extract

Values denoted by different superscripts in the column differ significantly $[\mathrm{p}<0.05]$

Table 2. Proximate Composition (\%) of smoked (Sardinella maderensis) preserved with Lemon (Citrus limon) oil during storage.

\begin{tabular}{|c|c|c|c|c|c|c|}
\hline Week & Moisture & Crude Protein & Lipid & Crude Fibre & Ash & NFE \\
\hline 1 & $7.35 \pm 0.07^{\mathrm{a}}$ & $42.75 \pm 0.35^{\mathrm{b}}$ & $8.40 \pm 0.14^{\mathrm{cd}}$ & $7.75 \pm 0.35^{\mathrm{ad}}$ & $6.90 \pm 0.14^{\mathrm{b}}$ & $26.75 \pm 1.06^{\mathrm{abc}}$ \\
\hline 2 & $6.90 \pm 0.14^{\mathrm{ab}}$ & $42.80 \pm 0.28^{\mathrm{b}}$ & $8.90 \pm 0.14^{\mathrm{abc}}$ & $7.90 \pm 0.14^{\mathrm{a}}$ & $7.45 \pm 0.07^{\mathrm{a}}$ & $26.05 \pm 0.07^{\mathrm{abc}}$ \\
\hline 3 & $6.70 \pm 0.14^{\mathrm{bc}}$ & $43.50 \pm 0.71^{\mathrm{ab}}$ & $8.60 \pm 0.14^{\mathrm{bcd}}$ & $7.65 \pm 0.21^{\mathrm{abc}}$ & $7.30 \pm 0.14^{\mathrm{ab}}$ & $26.30 \pm 0.00^{\mathrm{abc}}$ \\
\hline 4 & $6.70 \pm 0.14^{\mathrm{bc}}$ & $43.60 \pm 0.57^{\mathrm{ab}}$ & $8.45 \pm 0.35^{\mathrm{cd}}$ & $7.55 \pm 0.49^{\mathrm{abc}}$ & $7.20 \pm 0.28^{\mathrm{ab}}$ & $25.05 \pm 0.07^{\mathrm{c}}$ \\
\hline 5 & $6.35 \pm 0.21^{\mathrm{c}}$ & $42.80 \pm 0.42^{\mathrm{b}}$ & $8.70 \pm 0.28^{\mathrm{bcd}}$ & $7.45 \pm 0.07^{\mathrm{abc}}$ & $7.50 \pm 0.14^{\mathrm{a}}$ & $26.50 \pm 0.14^{\mathrm{abc}}$ \\
\hline 6 & $6.30 \pm 0.14^{\mathrm{c}}$ & $43.20 \pm 0.28^{\mathrm{ab}}$ & $8.10 \pm 0.14^{\mathrm{d}}$ & $3.80 \pm 0.28^{\mathrm{bc}}$ & $3.60 \pm 0.28^{\mathrm{f}}$ & $56.70 \pm 1.56^{\mathrm{d}}$ \\
\hline 7 & $5.65 \pm 0.21^{\mathrm{d}}$ & $45.35 \pm 3.04^{\mathrm{a}}$ & $8.65 \pm 0.21^{\mathrm{bcd}}$ & $7.40 \pm 0.28^{\mathrm{abc}}$ & $7.15 \pm 0.21^{\text {ad }}$ & $27.80 \pm 0.14^{\text {ad }}$ \\
\hline 8 & $5.55 \pm 0.21^{\mathrm{d}}$ & $43.80 \pm 0.42^{\mathrm{ad}}$ & $8.75 \pm 0.21^{\mathrm{bcd}}$ & $7.20 \pm 0.28^{\mathrm{bc}}$ & $7.15 \pm 0.21^{\mathrm{ad}}$ & $27.55 \pm 1.34^{\mathrm{ad}}$ \\
\hline 9 & $5.35 \pm 0.21^{\mathrm{d}}$ & $44.65 \pm 0.21^{\mathrm{ad}}$ & $8.75 \pm 0.35^{\mathrm{bcd}}$ & $7.10 \pm 0.14^{\mathrm{cd}}$ & $7.10 \pm 0.14^{\mathrm{ad}}$ & $27.05 \pm 0.64^{\mathrm{abc}}$ \\
\hline 10 & $5.25 \pm 0.21^{\mathrm{de}}$ & $44.55 \pm 0.07^{\mathrm{a}}$ & $8.90 \pm 0.42^{\mathrm{abc}}$ & $6.55 \pm 0.07^{\mathrm{de}}$ & $6.90 \pm 0.14^{\mathrm{b}}$ & $25.35 \pm 2.76^{\mathrm{bc}}$ \\
\hline 11 & $4.85 \pm 0.94^{\mathrm{ef}}$ & $44.75 \pm 0.07^{\mathrm{a}}$ & $9.25 \pm 0.35^{\mathrm{ad}}$ & $6.55 \pm 0.21^{\mathrm{de}}$ & $7.10 \pm 0.14^{\mathrm{ad}}$ & $27.50 \pm 0.85^{\mathrm{abc}}$ \\
\hline 12 & $4.40 \pm 0.14^{\mathrm{f}}$ & $44.55 \pm 0.07^{\mathrm{a}}$ & $9.50 \pm 0.42^{\mathrm{ad}}$ & $6.30 \pm .14^{\mathrm{e}}$ & $7.10 \pm 0.14^{\mathrm{ab}}$ & $28.15 \pm 0.64^{\mathrm{a}}$ \\
\hline
\end{tabular}

$\mathrm{NFE}=$ Nitrogen free extract

Values denoted by different superscripts in the column differ significantly $[\mathrm{p}<0.05]$ 
Table 3. Proximate Composition (\%) of smoked Bonga (Ethmalosa fimbriata) preserved with Lemon (Citrus limon) oil during storage.

\begin{tabular}{|c|c|c|c|c|c|c|}
\hline Week & Moisture & Crude protein & Lipid & Crude fibre & Ash & NFE \\
\hline 1 & $7.10 \pm 0.14^{\mathrm{a}}$ & $43.75 \pm 1.06^{\mathrm{ab}}$ & $8.85 \pm 0.21^{\mathrm{abc}}$ & $6.85 \pm 0.50^{\mathrm{a}}$ & $6.75 \pm 0.35^{\mathrm{a}}$ & $26.70 \pm 1.56^{\mathrm{a}}$ \\
\hline 2 & $7.05 \pm 0.14^{\mathrm{a}}$ & $44.00 \pm 0.71^{\mathrm{ab}}$ & $9.60 \pm 0.14^{\mathrm{e}}$ & $7.15 \pm 0.50^{\mathrm{ab}}$ & $6.94 \pm 0.09^{\mathrm{a}}$ & $26.65 \pm 0.35^{\mathrm{a}}$ \\
\hline 3 & $6.70 \pm 0.14^{\mathrm{b}}$ & $43.50 \pm 0.71^{\mathrm{ab}}$ & $8.60 \pm 0.14^{\mathrm{a}}$ & $7.65 \pm 0.21^{\mathrm{b}}$ & $7.30 \pm 0.14^{\mathrm{ab}}$ & $26.30 \pm 0.00^{\mathrm{a}}$ \\
\hline 4 & $6.60 \pm 0.14^{\mathrm{bc}}$ & $43.05 \pm 0.78^{\mathrm{ab}}$ & $9.35 \pm 0.07^{\mathrm{de}}$ & $6.85 \pm 0.50^{\mathrm{a}}$ & $6.85 \pm 0.50^{\mathrm{a}}$ & $26.30 \pm 0.14^{\mathrm{a}}$ \\
\hline 5 & $6.30 \pm 0.14^{\mathrm{cd}}$ & $42.75 \pm 0.35^{\mathrm{a}}$ & $9.35 \pm 0.21^{\mathrm{de}}$ & $7.20 \pm 0.28^{\mathrm{ab}}$ & $6.80 \pm 0.85^{\mathrm{a}}$ & $26.60 \pm 0.28^{\mathrm{a}}$ \\
\hline 6 & $6.10 \pm 0.14^{\mathrm{d}}$ & $43.05 \pm 0.35^{\mathrm{ab}}$ & $9.20 \pm 0.28^{\mathrm{bcde}}$ & $7.50 \pm 0.14^{\mathrm{ab}}$ & $7.50 \pm 0.42^{\mathrm{b}}$ & $26.80 \pm 0.57^{\mathrm{a}}$ \\
\hline 7 & $5.55 \pm 0.07^{\mathrm{e}}$ & $43.65 \pm 0.21^{\mathrm{ab}}$ & $8.90 \pm 0.14^{\mathrm{abcd}}$ & $7.65 \pm 0.21^{\mathrm{ab}}$ & $7.45 \pm 0.07^{\mathrm{ab}}$ & $26.55 \pm 0.21^{\mathrm{a}}$ \\
\hline 8 & $5.35 \pm 0.21^{\mathrm{e}}$ & $44.30 \pm 0.28^{\mathrm{b}}$ & $8.65 \pm 0.21^{\mathrm{a}}$ & $7.40 \pm 0.28^{\mathrm{ab}}$ & $7.75 \pm 0.0 .21^{\mathrm{ab}}$ & $26.55 \pm 0.21^{\mathrm{a}}$ \\
\hline 9 & $5.30 \pm 0.14^{\mathrm{e}}$ & $44.25 \pm 0.07^{\mathrm{b}}$ & $8.80 \pm 0.28^{\mathrm{ab}}$ & $7.30 \pm 0.14^{\mathrm{ab}}$ & $7.50 \pm 0.14^{\mathrm{ab}}$ & $26.85 \pm 0.50^{\mathrm{a}}$ \\
\hline 10 & $5.20 \pm 0.28^{\mathrm{e}}$ & $44.25 \pm 0.35^{\mathrm{b}}$ & $9.00 \pm 0.28^{\mathrm{abcd}}$ & $7.15 \pm 0.07^{\mathrm{ab}}$ & $7.30 \pm 0.14^{\mathrm{ab}}$ & $27.10 \pm 0.14^{\mathrm{a}}$ \\
\hline 11 & $4.10 \pm 0.14^{\mathrm{f}}$ & $44.20 \pm 0.14^{\mathrm{ab}}$ & $9.30 \pm 0.14^{\mathrm{cde}}$ & $7.25 \pm 0.35^{\mathrm{ab}}$ & $7.35 \pm 0.07^{\mathrm{ab}}$ & $27.80 \pm 0.42^{\mathrm{a}}$ \\
\hline 12 & $3.90 \pm 0.14^{\mathrm{f}}$ & $44.25 \pm 0.35^{\mathrm{b}}$ & $9.60 \pm 0.14^{\mathrm{e}}$ & $7.10 \pm 0.42^{\mathrm{ab}}$ & $7.55 \pm 0.07^{\mathrm{ab}}$ & $27.60 \pm 1.13 \mathrm{a}$ \\
\hline
\end{tabular}

$\mathrm{NFE}=$ Nitrogen free extract

Values denoted by different superscripts in the column differ significantly $[\mathrm{p}<0.05]$

Table 4. Proximate Composition (\%) of unpreserved smoked Bonga (Ethmalosa fimbriata) during storage.

\begin{tabular}{|c|c|c|c|c|c|c|}
\hline Week & Moisture & Crude protein & Lipid & Crude fibre & Ash & NFE \\
\hline 1 & $8.10 \pm 0.14^{\mathrm{l}}$ & $38.50 \pm 0.71^{\mathrm{i}}$ & $5.85 \pm 0.21^{\mathrm{f}}$ & $7.13 \pm 0.04^{\mathrm{l}}$ & $6.35 \pm 0.21^{\mathrm{g}}$ & $34.10 \pm 0.65^{\mathrm{a}}$ \\
\hline 2 & $7.70 \pm 0.14^{\mathrm{h}}$ & $35.75 \pm 1.06^{\mathrm{l}}$ & $5.50 \pm 0.42^{\mathrm{f}}$ & $7.05 \pm 0.07^{\mathrm{l}}$ & $6.20 \pm 0.28^{\mathrm{g}}$ & $37.80 \pm 1.98^{\mathrm{b}}$ \\
\hline 3 & $6.25 \pm 0.35^{\mathrm{g}}$ & $32.60 \pm 0.71^{\mathrm{l}}$ & $5.85 \pm 0.21^{\mathrm{f}}$ & $4.90 \pm 0.14^{\mathrm{h}}$ & $5.2 \pm 0.28^{\mathrm{ef}^{\mathrm{f}}}$ & $42.30 \pm 0.28^{\mathrm{c}}$ \\
\hline 4 & $6.30 \pm 0.14^{\mathrm{g}}$ & $32.40 \pm 0.57^{\mathrm{h}}$ & $4.45 \pm 0.35^{\mathrm{e}}$ & $4.90 \pm 0.14^{\mathrm{h}}$ & $5.35 \pm 0.21^{\mathrm{f}}$ & $46.60 \pm 0.71^{\mathrm{d}}$ \\
\hline 5 & $6.10 \pm 0.14^{\mathrm{g}}$ & $29.00 \pm 0.14^{\mathrm{g}}$ & $3.95 \pm 0.21^{\mathrm{de}}$ & $4.35 \pm 0.21^{\mathrm{g}}$ & $4.70 \pm 0.42^{\mathrm{de}}$ & $53.10 \pm 0.14^{\mathrm{e}}$ \\
\hline 6 & $5.30 \pm 0.14^{\mathrm{f}}$ & $25.50 \pm 0.71^{\mathrm{f}}$ & $3.80 \pm 0.28^{\mathrm{d}}$ & $3.60 \pm 0.57^{\mathrm{f}}$ & $4.60 \pm 0.14^{\mathrm{d}}$ & $53.10 \pm 0.14^{\mathrm{e}}$ \\
\hline 7 & $4.90 \pm 0.14^{\mathrm{e}}$ & $22.50 \pm 0.71^{\mathrm{e}}$ & $3.65 \pm 0.21^{\mathrm{d}}$ & $2.85 \pm 0.21^{\mathrm{e}}$ & $4.35 \pm 0.12^{\mathrm{cd}}$ & $61.75 \pm 1.06^{\mathrm{f}}$ \\
\hline 8 & $4.35 \pm 0.21^{\mathrm{d}}$ & $20.75 \pm 0.35^{\mathrm{d}}$ & $3.10 \pm 0.14^{\mathrm{c}}$ & $2.65 \pm 0.21^{\mathrm{de}}$ & $3.90 \pm 0.14^{\mathrm{c}}$ & $65.25 \pm 0.64^{\mathrm{g}}$ \\
\hline 9 & $3.90 \pm 0.14^{\mathrm{c}}$ & $19.25 \pm 0.35^{\mathrm{cd}}$ & $2.90 \pm 0.14^{\mathrm{bc}}$ & $2.30 \pm 0.14^{\mathrm{cd}}$ & $3.35 \pm 0.35^{\mathrm{b}}$ & $68.20 \pm 0.14^{\mathrm{h}}$ \\
\hline 10 & $3.10 \pm 0.14^{\mathrm{b}}$ & $17.7 \pm 0.35^{\mathrm{c}}$ & $2.65 \pm 0.21^{\mathrm{ab}}$ & $2.05 \pm 0.07^{\mathrm{bc}}$ & $3.10 \pm 0.14^{\mathrm{b}}$ & $71.35 \pm 0.35^{\mathrm{l}}$ \\
\hline 11 & $2.80 \pm 0.14^{\mathrm{b}}$ & $15.50 \pm 0.71^{\mathrm{b}}$ & $2.25 \pm 0.21^{\mathrm{ab}}$ & $1.74 \pm 0.20^{\mathrm{ab}}$ & $2.85 \pm 0.07^{\mathrm{ab}}$ & $74.90 \pm 0.99^{\mathrm{j}}$ \\
\hline 12 & $2.40 \pm 0.14^{\mathrm{a}}$ & $13.50 \pm 0.71^{\mathrm{a}}$ & $1.85 \pm 0.21^{\mathrm{a}}$ & $1.40 \pm 0.14^{\mathrm{a}}$ & $2.35 \pm 0.21^{\mathrm{a}}$ & $78.50 \pm 1.41^{\mathrm{k}}$ \\
\hline
\end{tabular}

NFE $=$ Nitrogen free extract

Values denoted by different superscripts in the column differ significantly $[\mathrm{p}<0.05]$

\section{Discussion}

All nutrients except Nitrogen Free Extract (NFE) in unpreserved sardine decreased all through the storage period. This shows that spoilage has not only made the fish unpresentable to consumers, it has also reduced its quality and as such affected its consumer acceptability. The consumer acceptability reduced by spoilage and consequently the nutrients for which consumers take fish. Although the moisture content and crude fibre in the preserved samples reduced, the reduction was not as significant $(\mathrm{p}<0.05)$ as it was in the unpreserved samples (Moisture content-7.35 to 4.40 (preserved sample), 7.65 to 2.10 (unpreserved sample), Crude fibre- 7.75 to 6.30 (preserved sample), 5.40 to 2.15 (unpreserved sample). The decrease in moisture content of the unpreserved sardine samples were in line with the Ayeloja et al., (2013) who reported same in smoked catfish not preserved with spices and stored for three months at ambient temperature. The reduction in the crude protein and lipid aligned with the findings of Taniya and Kannan (2016) who observed a decrease in the crude protein $(10.07 \%$ to $5.97 \%)$ and lipid (11.68 \% to $3.57 \%)$ of stored smoked Indian oil sardine. The crude protein content, lipid, ash and NFE increased significantly $(\mathrm{p}<0.05)$ throughout the storage period. This result showed that lemon essential oil was not only capable of preserving the fish from spoilage but also the nutrients for which consumers take it. Crude protein and lipid of preserved sardine samples for week 10 to 12 were not significantly $(\mathrm{p}<0.05)$ different from one another which therefore means that storing sardine for this long will still keep its nutrients intact, not only that, the same remarkable effect will be produced if it was stored for just 10 weeks. The ability of lemon essential oil to preserve sardine from spoilage and conserve its nutrients was also corroborat- 
ed by the reduction in moisture content $(7.35$ to 4.40$)$ which is a substrate for spoilage organisms to thrive. Crude fibre in the preserved samples decreased with increase in storage period and this disagreed with Ayeloja (2016) who reported a decrease in crude protein of smoked catfish preserved with garlic. This increase in fibre was attributed to the high fibre content of the preservative used which is low in lemon essential oil. The spices and herbs used by Taniya and Kannan (2016) also had a remarkably increase in fibre content of sardine which did reduced the crude protein.

Moisture content of bonga (Ethmalosa fimbriata) preserved with lemon essential oil significantly $(p<0.05)$ decreased with increase in crude protein, lipid, crude fibre, ash and nitrogen free extract which were not significantly $(p<0.05)$ different along the weeks throughout the storage period. This reduced moisture content showed that the keeping quality of preserved bonga improved with storage time because the condition for rapid bacteria growth was worsened [9]. The increased crude protein throughout the storage period was in line with Aberoumad and Pourshafi (2010) who stated that the lower the moisture content, the higher lipids and crude protein and the higher the energy density of the fish. All nutrients except NFE decreased significantly $(p<0.05)$ in unpreserved bonga samples. Lipids content decrease could be attributed to oxidation of the poly unsaturated fatty acids (PUFA) contained in the tissue of bonga to products such as peroxides, aldehydes, ketones and free fatty acids [12]. Daramola et al., (2007) also reported reduction in lipid in five different smoked freshwater fish species- Heterotis niloticus (bony tongue), Labeo coubie (African carp), Parachanna obscura (Snake fish), Oreochromis niloticus (Nile tilapia) and Clarias gariepinus (African mud catfish) during storage at ambient temperature for eight weeks. The ash content which is an indication of the mineral content of the fish [4] reduced significantly throughout the storage period compared to its preserved counter parts. Consequent to the decrease in other nutrients in the unpreserved bonga samples, the NFE increased considerably and significantly $(\mathrm{p}<0.05)$. This thus infers that the degradation of the protein and other nutrients during spoilage increased the non-protein nutrients $[11,18]$.

\section{Conclusion and Recommendation}

It can thus be concluded from the results of this study that Lemon essential oil had a significant effect on the nutritional components of Clupeids (Ethmalosa fimbriata, Bonga and Sardinella maderensis, Sardine) because of its ability to conserve both its nutrients throughout the storage period. As such lemon essential oil can be used as a preservative for fish as evidenced in the improved nutrient content of preserved samples with increase in the storage period. Shelf life extension of fish is a must do, if reduction of post-harvest losses will be achieved. In doing this, the use of natural preservatives for fish is a major step towards promoting the consumption of properly preserved and healthy fish products. Therefore the following are recommended from this study;

1. Despite the conversion of waste to wealth, extraction of lemon essential oil from its peels is expensive. Large scale production of lemon essential oil in industries could be encouraged to reduce the cost of extraction.
2. Lemon peel essential oil can be depended upon as a preservative for fish because it was able to preserve clupeids for a period of three months, thereby conserving its nutrients.

3. Citrus essential oils from other citrus species such as sweet orange (Citrus sinensis), tangerine (Citrus reticulata) and lime (Citrus aurantifolia) can be experimented to see if similar effects will be produced.

4. Infusion of lemon essential oil into thin permeable materials which can then be used wrap the fish to see the preservative effect on the fish.

\section{References}

[1]. Aberoumad A, Pourshafi K. Chemical and Proximate Composition Properties of different Fish species obtained from Iran. World J. Fish. Mar. Sci. 2010; 2: 237-239.

[2]. Abolagba OJ, Igbinevbo EF. Microbial Load of Fresh and Smoked fish Marketed in Benin Metropolis, Nigeria. Journal of Fisheries and Hydrobiology. 2010; 5(2): 99-104.

[3]. Abowei JFN. The Abundance, Condition Factor and Length-Weight Relationship of Sardinella maderensis (Jenyns, 1842) from Nkoro River, Niger Delta, Nigeria. Advance Journal of Food Science and Technology. 2009; 1(1): 66-71.

[4]. Adeleke RO, Odedeji JO. Functional Properties of Wheat and Sweet potato Flour blends. Pakistan Journal of Nutrition. 2010; 9(6): 535-538.

[5]. Cunniff P. Official methods of analysis. Association of Official Analytical Chemists (AOAC). 16th ed. Arlington, Virginia, USA. 1995.

[6]. Ayeloja AA. Evaluation of the Effects of Natural Preservatives and Packaging Materials on the Shelf life of Smoked African Mud Catfish (Clarias gariepnus, Burchel 1822). Thesis submitted the Department of Aquaculture and Fisheries Management, Federal University of Agriculture, Abeokuta. Ogun State. 2016.

[7]. Ayeloja AA, George FOA, Dauda TO, Jimoh WA, Popoola MA. Nutritional Composition of Captured Clarias gariepinus and Oreochromis niloticus. International Research Journal of Natural Science. 2013; 1(1): 9-13.

[8]. Belitz HD, Grosch Werner, Schieberle P. Food Chemistry. 4th Revised and Extended Edition. Published by Springer. 2009; 8-24.

[9]. Boran G, Koracam H. Seasonal Changes in Proximate Composition of some Fish Species from the Black Sea. Turkish Journal of Fisheries and Aquatic Sciences. 2011; 11(1): 1-5.

[10]. Daramola JA, Fasakin EA, Adeparusi EO. Changes in Physicochemical and Sensory Characteristics of Smoked-dried Fish Species stored at ambient Temperature. African Journal of Agriculture, Nutrition and Development. 2007; 7(6).

[11]. Dewey T, Shefferly N, Havens A. Animal Diversity Web. University of Michigan Museum of Zoology. 2010.

[12]. Gueraud F, Atalay M, Bresgen N, Cipak A, Eckl PM, Hucl L, et al. Chemistry and Biochemistry of Lipid Peroxidation Products. 2010; 44(10): 1098124. PMID: 20836659.

[13]. Hilderbrand K. OSU Extension Specialist, Personal Communications. 1995.

[14]. Idodo-Umeh G. Freshwater Fishes of Nigeria (Taxonomy, Ecological Notes, Diets and utilization) Idodo Umeh Publishers Ltd. Benin City. 2003; 232.

[15]. Olokor JO, Ihuahi JA, Omojowo FS, Falayi BA, Adelowo EO. Handbook of Practical Fisheries Technology. Fisheries Technology Division. National Institute for Freshwater Fisheries Research (NIFFR). New Bussa, Niger State Nigeria. 2007; 22-9.

[16]. Adebisi O. Comparative study of essential oil composition of fresh and dry peel and seed of Citrus sinensis (L) Osbeck var shamuti and Citrus Paradise Macfadyen var Marsh. Ife Journal of Science. 2014; 16(2):211-7.

[17]. Osibona AO, Kusemiju K, Akande GR. Proximate composition and fatty acids profile of the African Catfish Clarias gariepinus. Acta Satech. 2006; 3(1):85-9.

[18]. Sanders DH. Statistics. A First Course (5th Edtn). New York. McGraw-Hill. 1990.

[19]. Alex T. Effect of spices and herb for enhancing microbial quality and shelf life of dried Indian oil sardine (Sardinella longiceps) fish during storage at room temperature. IOSR Journal of Environmental Science, Toxicology and Food Technology. 2016; 10: 44-51. 